\title{
COVID-19 lessons: experience in organization of distance pre- school education
}

\author{
Odeta Merfeldaitè \\ o.merfeldaite@mruni.eu \\ Mykolas Romeris University, Lithuania

\section{Romas Prakapas} \\ prakapas@mruni.eu \\ Mykolas Romeris University, Lithuania
}

\section{Asta Railienè}

asta.railiene@mruni.eu

Mykolas Romeris University, Lithuania

\begin{abstract}
The article is for analysis of new experience in the national context - organisation of distance education in preschool education and the challenges in application of the innovation, when the implementation as such has not been planned and modelled for getting ready for it in advance. In Lithuania, before the COVID-19 pandemic distance education in the preschool education meant for reparation of a child ready for school was not applied, there were no specific guidelines, tested teaching platforms or pedagogic practices. The study deals with the results of a focus groups research performed in June of 2020, designated for discussing of experiences of the Lithuanian preschool education institutions in distance education gained during the quarantine (16/03/2020 to 29/05/2020). The performed analysis of experiences in organisation of distant education in preschool education disclosed the essential challenges faced when applying this form of education in the education of six-year-old children. It has been established that the key challenges organizing distance education in the preschool education are related to lack of the IT solutions for distant education; readiness of the participants of the education process for distant education and engagement into such process of education, as well as the lack of support from national and regional institutions in organisation of distant education. The results of the research open possibilities for further researches which are necessary for efficient and sustainable distant education integration into preschool education. In this background, explicit, deep research related to analysis of appropriateness of distance education platforms in the stages of early age, search for didactic solutions of digital content for them and deep researches of implementation cases and etc. is necessary.
\end{abstract}

\section{Keywords}

Preschool education, organisation of education, distance education, COVID-19 


\section{Introduction}

The pandemic occurred in the end of 2019 - beginning of 2020 strongly affected all areas of human life. According to the data of the World Economic Forum, globally, due to the COVID-19 pandemic almost 1.6 billion children in 195 countries could not normally study in their classrooms. Such physical close-down of schools caused a threat not only to the child's right to education, but it also directly relates with decrease of human capital and economic potentials in the long-term prospective. Educators and scientists of educology rushed to search for ways out of the occurred situation. The existing technologies designated for distance teaching and self-learning were newly reconsidered looking for optimal solutions in the context of the present situation (Machynska \& Dzikovska, 2020; Terenko \& Ogienko, 2020). Aiming to mitigate the threats, educational institutions switched to distance education. According to Roache, Rowe-Holder \& Muschette (2020), the positive aspect of the crisis is that it stimulated development of distance education. On one hand, it is believed that such unplanned, fast and unprepared switch to distant education might give negative experiences in this form of education and interfere with development of innovations in education. On the other hand, it is presumed that this experience will allow modelling of a new, hybrid model of education and will facilitate the integration of information technologies into the processes of (self-) education, and distance education will become an inseparable part of education (Li \& Lalani, 2020).

According to Tam and El-Azar (2020), COVID-19 turned into a catalyst allowing institutions of education in the whole world look for innovative solutions, which directly associate with faster implementation of innovations into organization of (self-) education process and development of partnership between of public and private sectors. It is noted that the traditional (self-) education in a classroom will be supplemented with new methods - starting with live broadcasting, finishing with experiences of virtual reality, this way implementing the concept of digital education - (self-) education "anywhere and anytime". According to the authors, the pandemic even more actualized the partnership between business and education sectors which has been growing during the past ten years.

With the improvement of new communication technologies, distance education may grant rich, authentic ecology of learning which may facilitate cooperation and inter-dependency of those who learn (Alphameric \& Khan, 2016). But the type and the design of technological means and platforms, the pedagogic methods applied have direct impact on the quality and engagement in children's education (Faria et al, 2019). It should be noted, that if digital technologies are applied in smart and correct ways, they may ensure more individualised, more flexible and child-orientated education (Digital Education Action Plan 2021-2027, 2020).

The opinions of scientists about distant education in the early stage of age are different. There are researchers who believe that in the early education it is necessary to use ICT, to use distance education up to certain scale, and that it might help to the child's development. But on the other hand, it should not be forgotten that technologies might associate with risks and limitations (Plowman et al. 2011; McPake, Plowman, \& Stephen, 2013). Scientists (Elkind, 2007; House, 2012) state that distance education may not be used in the early stage of age as it does not allow to prepare children socially and emotionally ready for school (Edwards et al, 2012), and that it might impair their health and development (Dong, Cao, \& Li, 2020). Children of preschool age in distance education might experience social isolation, lack of inter-activity and involvement.

Regardless of the discussion, distance education in the early education may provide children with creative and communicative activities (Kim, 2020). Scientists (Clements \& Sarama, 2003; Yelland, 2006) confirm that digital education may help the preschool children to understand abstract concepts surrounding them, and to engage them into learning, reasoning and problem solution activity for development (Dong, Cao, \& Li, 2020). Arnott \& Yelland (2020) state, that distance 
education should be considered "a part of multi-modal life of the world"; therefore, it should be contextualised. It is noted that it is important to create a safe and healthy on-line environment, fit for children, by improving their reasoning aptitude (McPake, Plowman, \& Stephen, 2013; Manches \& Plowman, 2017; Edwards et al., 2018). In the education of preschool children during the COVID-19 period the engagement of adults into children's distance education processes is emphasized (Schroeder \& Kelley, 2010; Youn, Leo \&Lee, 2012), as well as the selection of appropriate education means which would encourage participation and involvement of children.

Participation in preschool education has long-term benefits not only for development in the childhood, but also in further life of the person. Qualitative early education of children is an effective means building the foundation for a positive trajectory of children's development (Campbell et al., 2012; Reynolds, Ou, \& Temple, 2018), for cognitive processes and socioemotional development of children. (Chor, 2020). In order to secure the quality of the early education, in Lithuania a lot of attention is paid to education of the child in the last year before starting school. In the country from 2016 mandatory general preschool education has been implemented - a one-year program which is designated for getting the child ready for school. This education in Lithuania starts at the age of 6 . Though during the recent decade there has been a lot of discussions about the use of digital technologies in the early education, which possibly might contribute to the quality of the early education of children (Kim,2020), but in Lithuania before the COVID-19 pandemic distance education was not in use in the preschool education; there were no education guidelines, tested education platforms, pedagogical practices. Therefore, in spring 2020, in result of the occurred extreme situation and having switched all education to distant environments, education institutions working with six-year-old children faced tremendous challenges in organisation and application of such form of education, which associated not just with technological solutions, but also with readiness of the participants of the education process for distance education and the absence of any external support system. With the absence of such pedagogical practices it is very important to analyse what the real experiences in the preschool organization institutions from the COVID-19 period are. What challenges were faced by education institutions in organization and implementation of distance education in the period at issue?

The object of the research is the experience of the Lithuanian education institutions carrying out preschool education in the COVID-19 period (from 16/03/2020 to 29/05/2020).

\section{Materials and methods}

\section{a. Method}

Aiming to disclose the experiences of preschool education institutions in organization of distance education, the research was performed applying methodological approach of qualitative research (Creswell \& Creswell, 2018). The basic method for data collection - a discussion of the focus groups (Onwuegbuzie et al, 2009, Liamputtong, 2011) was selected due to the specifics of the method which allows discussing different experiences of the participants, generating new ideas, specifying the available knowledge, foreseeing possibilities for improvement of the situation. 


\section{b. Participants}

Firstly, members for the focus group were selected by a common feature - deputies for education working at schools of general education which perform preschool education programs. This helped to secure that all members of the focus groups have mutual interests and experiences (in organisation of distance education in preschool education). Further, selection by criteria was applied. The participants of the discussion were selected based on the following criteria: (1) regionality - deputies for education from different regions, from city /countryside institutions working with six-year-old children were invited to the focus groups (2) pedagogic and managerial experience - participants having at least five years of managerial and pedagogic experience were invited for the discussions in the focus groups. Such method of selection allowed to select for research typical cases, by this ensuring the quality of the research data.

Three discussions of such focus groups were organised (each group was encoded as F1, F2, F3) where 18 deputies for education of the education institutions that carried out preschool education participated. No persons who would be inter-related (colleagues, hierarchically subordinated persons) were present in one group. All participants in the research were females, their pedagogic and managerial experience exceeded five years. The participants represented different regions, both city and countryside schools. Such variety of participants in the research allowed to disclose versatility of the investigated phenomenon and to avoid limitations which might have negative influence on the data of the research.

\section{c. Procedure and data analysis}

The research was performed in the end of June 2020. Participants of the discussions were in advance informed about the research (educational institutions were contacted by telephone, by emails), and a week to a meeting of each group it was once again inquired about the participation; in case of the negative answers, new participants for the research were looked for additionally, following the established criteria, seeking to secure the optimal size of the focus group. The average duration of the focus group discussion was $2.5-3$ hours. The focus group discussion was organised applying the methodology of adapted active meeting (criticism, advantages, suggestions) (Kjærgaard and Martinenienè, 1998) - the participants in the research discussed their experiences in organisation of distance education during the quarantine (from 16/03/2020 to 29/05/2020). All participants in the research were introduced to the purpose of the research, the specifics of the focus group discussion method. Following the provisions and principles of the qualitative research performance ethics (Miller et al, 2012), all participants took part in the research voluntarily, no names of the participants were disclosed while processing the data of the research, in presentation of illustrations only the codes of the participants are indicated (generated by participation in individual groups - F1.1, F1.2 ... F.3.1 F3.2 and etc.) The data of the research were fixed and recorded on Dictaphone. Prior to recording the data, consent of the participants of the research regarding recording was obtained. Additionally, one of the performers of the research noted speaking of the participants and notes of the researchers in written. All groups were moderated by the same person, one of the organisers of the research. The empiric data of the research have been processed using the method of inductive thematic analysis (Corbin \& Strauss, 2014). The obtained empiric data were analysed following the methodological recommendations of six steps (King \& Brooks, 2018): having transcribed the discussion texts of all groups, they were carefully revised; then the obtained texts were encoded by highlighting semantic units in the text; the next step - linkage of the present semantic units by the highlighted topics, then the revision of formulated topics, and finally, definition of the distinguished topics and preparation of the final report on the research. 
Based on Cohen, Manion and Morrison (2013), Patton (2014), Hayashi, Abib and Hoppen (2019), the validity of the study was ensured in the following ways: (a) openness to the phenomenon under investigation. A specific definition of the phenomenon under the study was not presented to the research participants, so that the researchers' understanding of the phenomenon was not imposed on the participants; (b) the method of the data collection was based on open-ended questions that encouraged openness and subjective experience of the phenomenon by the research participants; (c) the collaboration between the researchers in the process of collecting, analysing and interpreting the research data. The researchers focused on discussion in the process of the data analysis and interpretation. At each stage of the data analysis, the researchers discussed interim research insights, interpretations of the research data, generalisations and conclusions, in order to reach a conceptual and informed decision. Such collaboration helped to avoid one-sided opinions and false conclusions and contribute to ensuring communicative validity check (Kvale, 1994); and (d) detailed description, clarity and visualisation of the data. The data were analysed on the basis of the map of themes developed for the data, which reveals not only the themes and sub-themes but also the internal relationships between themes and sub-themes.

\section{III: Results of the research}

In the discussions of the focus groups on the experiences of the deputies for education in organisation of distance education during the COVID 19 pandemic, three topics stood out: (1) fundamental (ontological) issues, (2) readiness of participants of education process for distance education and (3) external support system (see Fig. 1).

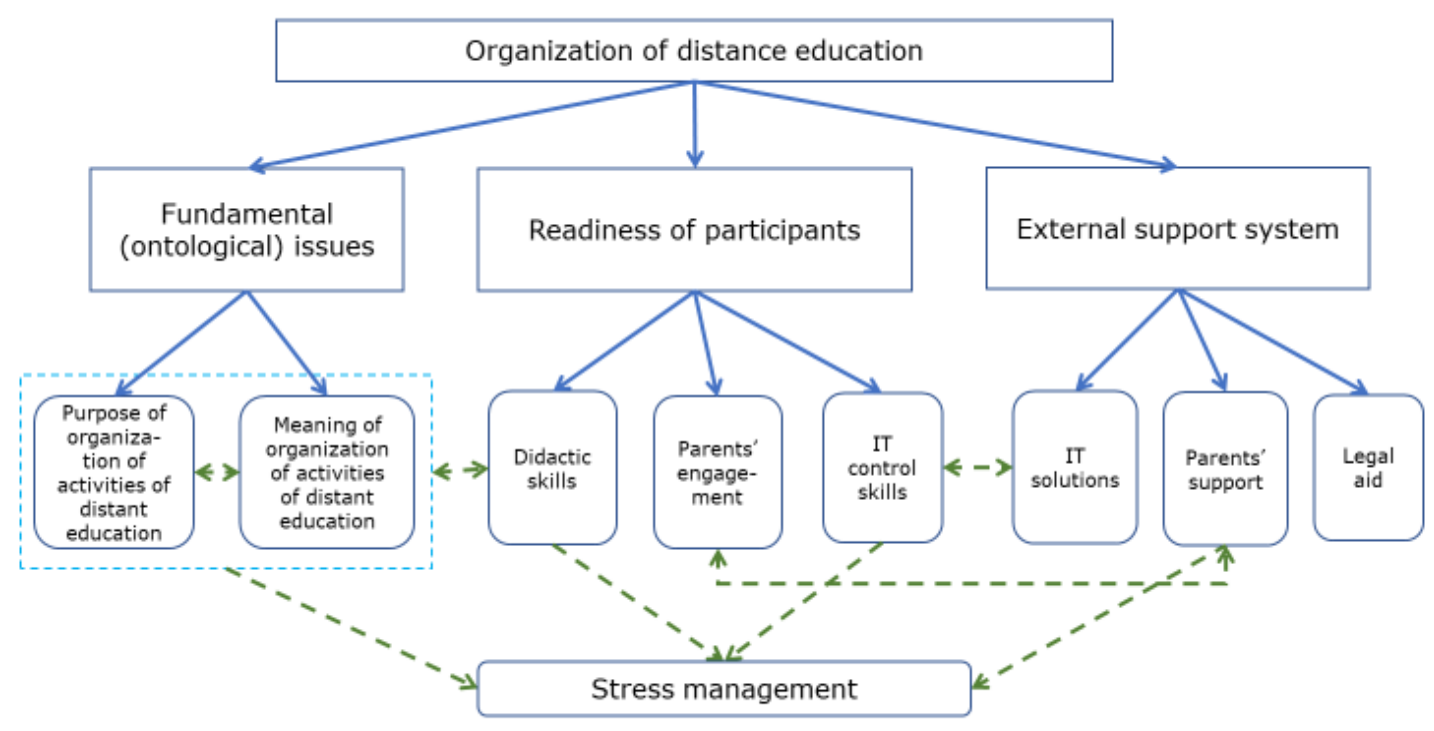

Figure 1. Map of the themes of distance education organisation 


\section{a. The theme of fundamental (ontological) issues}

The theme of fundamental (ontological) issues is revealed by two sub-themes: the sense of organising distance education activities and the purpose of organising distance education activities. At the initial step of research data processing certain codes started to appear, which on the semantic level guided to the philosophical search for meaning. A discussion of ontological nature ("work - is it really necessary" [F1.4]; "who needs it" [F3.1]), where certain fragments of meaningfulness and senselessness often would interlace with the issues of the purpose of organization of distant education ("distant education in preschool education may only be instantaneous, it may not last continuously"[F2.2]; "regulation of the content of education is in no way related to the situation $\langle\ldots\rangle$ the content of education has quite another purposes" [F1.1]). During the discussions an attempt of the participants in the research to look for arguments stood out, comparing themselves again and again with the situation of schools of general education, emphasizing that their pupils do not have the skills that senior children have. All this would later on turn into discussions covering competences of the teachers, and as often as not, of the deputies for education as well.

The analysis of the research data content shows certain links between the sense of distance learning and the didactic competences of pedagogues. Often statements of the participants in the discussions about the sense "-what is the sense of all this" - would be accompanied by comments and replies that "no one had ever taught of this" [F1.5], "no means for this has been prepared" [F1.3]. More than one of the participants in the discussions repeated reflections of the teachers from their educational institutions "-it is easy to tell how to work" [F3.4], "tell us how to use the methods of education that children are used to at the computer" [F2.5] and etc. It is obvious that didactic solutions and the existing skills of use of distance education and ICT overlap. Which, in its turn, associates not just with the inner resources, but also with the external support system. At least during the first weeks, no external support was provided ("teachers were left alone - just do it, do as you wish" [F2.1]).

\section{b. The theme of readiness of pre-school institutions for distance education}

The theme of readiness of pre-school institutions for distance education is revealed in three subthemes: didactic skills, parents' engagement and IT management skills. Analysing the research data, the subject of readiness for distance (self-) education by the participants of the process of education was distinguished indeed, highlighting unevenness in managerial work and professional and general competences. Routine elements of managerial work have changed and challenges arose -" resistance of teachers" [F2.4]; "the older is the teacher the more complicated is the situation" [F3.6]; "high exhaustion of teachers, of administration" [F2.1]. All this went in parallel with the increasing workload of deputies for education of education institutions carrying out preschool education ("increased work load" [F3.3]; "unlimited work hours, often over 14 hours per day" [f3.5]; "more work than normally" [F1.3]. On the other hand, the institutions of preschool education were not given any opportunity to get ready for distant education on the national level. In this situation the deputies for education of pre-school institutions "lacked certain information on how one has to work" [F1.6], "instructions from Municipalities turn into recommendations $\langle\ldots\rangle$, clarity is missing, confusion" [F3.4], "much of not systematised and chaotic information" [F2.1] and etc.). Attempts to use the means used by other pedagogues working with children also caused a problem ("everybody kept telling -ZOOM, ZOOM<...> but how to work with it?"[F3.2]; "I heard about Padlet in a seminar, but it was not so good for our children" [F2.1], and etc.), moreover, very limited technical capacities of many educational institutions came out ("lack of IT tools"[F2.2], "internet would break, it took long time to get provided"[F1.1, "not all pupils had the required 
equipment" [F3.2] and etc.) and even better highlighted the gaps in managerial and general competences.

Though in the discussion groups all participants in the research paid a lot of attention to the challenges they had faced personally, but during the discussion some positive issues, which were taken by the majority of the participants in the research as useful lessons both for themselves and the very system of education, started to appear. The same as in the discussions on the problems, and on discovering personal successes, the participants in the research often spoke about own and pupils' competences ("tremendous progress, we've learned much" [F2.3], "leadership has unfolded" [F2.2], "the acquired experiences will be forwarded..." [F1.1] and etc.). In the conversations not just formally improved or gained management competences in "information and communication technologies" [F1.4] came out, but also other general competences (socialising and cooperation, problem solution and etc.) were very noticeable. Participants of more than one group spoke about "cooperation" [F1.3], "team solidarity" [F3.6] or highlighted "creativity" in the strengthened community. The experience of several months in distance education, in the opinion of the deputies for education of the education institutions carrying out preschool education, is priceless not only because of new and improved competences, but also because of the solidarity of the community (the educational institution itself, social partners (publishing houses, universities, centres)). Analysing the research data in respect of possible suggestions regarding further work, based on the newly gained experience, it is possible to distinguish clear directions for improvement of competences ("digital training with practice" [F3.4]; "training of pedagogues for work with different platforms" [F2.3]; "distance qualification events" [F1.3]; "cooperation of teachers in development of general and integrated activities" [F1.3] and etc.).

\section{c. The theme of an external support system}

The theme of an external support system is covered by three sub-themes: IT solutions, parental support and legal aid. On both, the national and the municipal level, guided support was welcome, but "the lack of centralised platform" F2.3];" environments which are suggested for use are orientated towards senior children" [F2.1] disclosed the gaps of supply of the external support. Heads of education institutions noted that elementary legal issues regarding the change of work form after the transfer to distance education had not been considered ("how to help the children who have special needs in education" [F3.4;"how the specialist of assistance to child shall work" [F1.6];"data protection concern" [F1.1] and etc.). In the absence of operative assistance provided in due time, most of the heads of educational institutions turned to the parents of their pupils. Because of both, the age of the children and the skills to use IT independently, and expecting for constructive cooperation. Here again some latent phenomena came out - how much the parents had been engaged into the process of education in conventional activities, what were the skills of teachers to cooperate with parents ("parents' expectations are different" [F3.2]; "engagement of parents differ" [F3.3]; "unwillingness of parents to cooperate" [F1.4]; "different attitudes towards responsibility" [F2.2] and etc.). After some time, the pedagogues state noticing that parents also got it as a challenge, as they had to do their own works at home and at the same time to help children to participate in the activities of distance education. The problem is that parents did not always know how and in what way they could help, their pedagogical "absence of feedback" [F1.1] and IT competences ("lack of IT competences in children and their parents" [F2.6] were also limited.

All the above caused tension and increased the systematic and chaotic uncertainty and indefiniteness of the situation. And finally, after the quarantine was formally over, the caused stress was felt for long time further on ("physical -emotional-psychological tension" [F2.1]; "fear, uncertainty, what if ..." [F3.3] and etc.). 
The analysis of the results of the study revealed positive aspects in the experiences of the participants. Organisation of distance education, in the assessment of the participants in the research, was an excellent opportunity to recall other forms of education organisation and to try them practically not just on the pupils or colleagues, but on the parents as well. Pedagogues newly assessed and actualised for themselves the importance of the parents' role in the process of education ("participation of parents in education" [F2.1]; "virtual communication with parents has improved" [F2.5]; "virtual parents' meetings attracted more parents than the usual ones' [F3.2]). The deputies for education that participated in the research noted that "the increase of the teacher's standing, responsibility" [F2.2] was noted in communication with the parents. Communication with parents in schools became "much more intensive" [F2.1] as never before. As one of major successes the deputies for education indicated "communication and cooperation with parents became more constructive" [F1.4], and this provides conditions for purposeful education of children.

The research data analysis highlighted the suggestions of the participants for improving external support ("re-modelling of education content allocating a sufficient number of non-contact hours" [F1.6]; "development of education platforms" [F2.4]; "support of distance education elements also in the non-quarantine period" [F2.5]; "development of the methodological base" [F1.5] and etc.) and guided modelling and provision in due time. Some of the measures ("supply of IT technologies" [F2.1]; "provision of quality headphones, microphones, cameras" [F2.4]; "clear regulations and recommendations" [F3.2] should be prepared in advance, preventively. This would allow mitigation of arising stress and unnecessary tensions.

\section{Discussion and findings}

The performed analysis on experiences in organisation of distant education in early education of children disclosed the essential challenges faced when applying this form of education in the education of six-year-old children. The newest results of scientific investigations emphasize three conditions necessary for smooth organisation of distance education: qualitative access to the Internet, appropriate technologies and skills to use them (National Education Responses to COVID-19, 2020). The quality of distance education depends very much on the level of digital access and the quality of digitisation of all participants in the (self-) education (teachers, pupils, parents) (Li \& Lalani, 2020; Tam \& El-Azar, 2020; Jaisinghani, 2020). Our results echo the results of the relevant scientific investigations which actualise one of the key problems in use of distance education - lack of competences of teachers in the application of IT in the education process (Konca et al, 2016; Lindahl and Folkesson, 2012; Yurt \& Cevher-Kalburan, 2011). Though readiness of teachers is one of the key components of the learning ecosystem which have influence on sustainability of distance education (Giovannella, Persico \& Passarelli, 2020), insufficiency of teachers' readiness to organise education in the distant way came out during the course of the research. With the commencement of mandatory distant education teachers had to spend considerably more time for preparation to adapt the content of education for organisation of distant education. This was one of the main stressors causing tension for the teachers. This responds to the results of other scientific investigations which have established that a big part of distant (self-) education success depends on readiness of the teacher to integrate technologies into own teaching practice (König, Jäger-Biela \& Glutsch, 2020) and his motivation for doing that (Levin, Whitsett \& Wood, 2013; Beetham \& Sharpe, 2013; Imlawi, Gregg \& Karimi, 2015; González-Patiño, 2018). Specifically, the teachers, when organising education process, have to consider the level of children's development and to find appropriate means for (self-) education which would encourage 
participation and learning of the children. Children of preschool age might not have proper technological skills which are required for performance of tasks of distant education. But different functions and tools of video communication platforms might be useful for children's self-education, providing teachers use them properly (Preradovic, Lesin, \& Boras, 2016; Kim, 2020). It is important to create a safe and healthy on-line environment, fit for children, improve their reasoning aptitude and understanding of education technologies (Edwards et al, 2018; Kim, 2020). Special attention should be paid to readiness of teachers to apply distance education means when working with the children with special needs of education (Fernández Batanero, Román Graván, \& Siles Rojas, 2020). This especially actualises the necessity for teachers to consider individual differences of children and the level of their education. Teachers have to consider different needs of each child, his style of learning, personality and likes. Distance education limits equal involvement of children into the process of education; therefore, aiming to secure equal possibilities for all children to engage into the process of education, teachers must create attractive virtual environment (Enrique Agudo, Rico, \& Sánchez, 2015; Kim, 2020).

Scientists (Willis \& Exley, 2018; Makrooni, 2019; Woofter, 2019) emphasize the importance of parent support to the child's learning for the success in the virtual education environment. This relates to acceptance of new roles and responsibilities by the parents (Liu et al., 2010). By the study we have established that the period of distance (self-)education opened new possibilities for cooperation with parents via distant platforms, provided assumptions for more active participation of parents in the process of their children (self-)education. Parents, being the main part of the child's closest surroundings, have influence on learning and improvement of their children. Beliefs and attitudes of the parents towards distance education of preschool children might have influence on the quality and potentials of distant education (Erdogan et al, 2019). By the research it was established that organisation of distance education allowed testing another forms of education organisation. Conditions for personalisation of education were created. This echoes the results of other researches where it is emphasized that distance (self-)education gives flexibility to education as the students may use education resources irrespectively of time and distance (Orr, Weller \& Farrow, 2019; Stone, Freeman et al., 2019). Such form of education makes the process of education more comfortable, brings it closer to the student's possibilities and is more cost-effective (Renner, Laumer \& Weitzel, 2014).

The analysis of the results of the research disclosed that the absence of IT solutions for distance (self-) education in the institutions of preschool education is linked to the limited technical potentials of many institutions, which prevent proper performance of distant education. As the lack of technical possibilities increases inequalities among the students (COVID-19 is reviving the need to explore on-line teaching and learning opportunities, 2020), the role of the incorporator should be emphasized by increasing financial funds and technical support allocated for schools. Our researched showed that qualitative distance education is not possible without the external support of various levels. Such transfer in a rush to new practice in the early stage education -distance education - disclosed the necessity of support to both, the teachers and the parents, from the environment: politicians of education, incorporators of the institutions, administrations. The support should be associated with financial and technical support, development of a unified legal base, provision of advisory assistance. Those results of our research comply with the results of the most recent of scientific research, which note that during the quarantine in many countries cooperation between various interested parties - education specialists and politicians, publishers, technology providers and telecommunication networks operators, IT consultants - has improved (Tam \& El-Azar, 2020).

Our study is meant for analysis of the new experience in the national context - organisation of distance education in early preschool education and the challenges in application of the innovation, when the implementation as such has not been planned and modelled getting ready for it in 
advance. The results of the research open possibilities for further research which are necessary for efficient and sustainable distant education integration into the early stage education. One of the insights for further investigation is the challenge of formation and increase of digital exclusion. Scientific researches (Miño Puigcercós, 2018; Li \& Lalani, 2020; Tam \& El-Azar, 2020; Jaisinghani, 2020) draw attention to rapidly increasing and extremely standing out in the period of pandemic digital exclusion. Digital exclusion may particularly increase if accessibility of education is directly related to the possibility to use the most advanced technologies. Another direction traced for research is didactic solutions for organisation of distance education. Scientific researches emphasize that children in their early age are very willing to engage in various digital contents, but how the existing digital content, not just its simplicity of interactive design, distribution of elements on the screen and etc., correspond to the principles and the goals of the early education and correlate with the specifics of education of young age children (Grané, \& Crescenzi, 2016). In this background, explicit, deep research related to analysis of appropriateness of distance education platforms in the stages of early age, search for didactic solutions of digital content for them and deep researches of implementation cases and etc. are necessary.

\section{References}

Aldhafeeri, F. M., \& Khan, B. H. (2016). Teachers' and students' views on E-Learning readiness in Kuwait's secondary public schools. Journal of Educational Technology Systems, 45(2), 202-235. https:// doi.org/10.1177/0047239516646747

Arnott, L., \& Yelland, N. (2020). Multimodal lifeworlds: Pedagogies for play inquiries and explorations. Journal of Early Childhood Education Research, 9(1), 124-146.

Beetham, H., \& Sharpe, R. (Eds.). (2013). Rethinking pedagogy for a digital age: Designing for 21st century learning (2nd ed.). New York: Routledge

Campbell, F. A., Pungello, E. P., Burchinal, M., Kainz, K., Pan, Y., Wasik, B. H., Barbarin, O., Sparling, J. J., \& Ramey, C. T. (2012). Adult outcomes as a function of an early childhood educational program: An Abecedarian Project follow-up. Developmental Psychology, 48, 1033-1043. https://doi.org/10.1037/ a0026644.

Chor, E. (2020). Unequal Impact: COVID-19 and Early Childhood Education. Policy Brief, 4, September 3. https://liberalarts.temple.edu/sites/liberalarts/files/ppl\%20policy\%20brief\%20no.4 090320.pdf

Cohen, L., Manion, L., \& Morrison, K. (2013). Research methods in education. London: Routledge. doi: $10.4324 / 9780203720967$

Clements, D. H., \& Sarama, J. (2003). Young children and technology: What does the research say? Young Children, 56(6), 34-35.

Communication from the Commission to the European Parliament, the Council, the European Economic and Social Committee and the Committee of the Regions Digital Education Action Plan 2021-2027. Resetting education and training for the digital age. Brussels, 30.9.2020 $\operatorname{COM}(2020) 624$. https:// ec.europa.eu/transparency/regdoc/rep/1/2020/EN/COM-2020-624-F1-EN-MAIN-PART-1.PDF

Corbin, J. \& Strauss, A. (2014). Basics of Qualitative research. Thousand Oaks: SAGE.

COVID-19 is reviving the need to explore online teaching and learning opportunities (2020). EPALE. https:// epale.ec.europa.eu/en/blog/covid-19-reviving-need-explore-online-teaching-and-learningopportunities

Creswell, J. W., \& Creswell, J. D. (2018). Research design: Qualitative, quantitative, and mixed methods approaches. Los Angeles London New Delhi Singapore Washington DC Melbourne: SAGE.

Dong, Ch., Cao, S. \& Li, H. (2020). Young children's online learning during COVID-19 pandemic: Chinese parents' beliefs and attitudes. Children and Youth Services Review, 118. https://doi.org/10.1016/ j.childyouth. 2020.105440 
Edwards, S., Mantilla, A., Henderson, M., Nolan, A., Skouteris, H., \& Plowman, L. (2018). Teacher practices for building young children's concepts of the internet through play-based learning.Educational Practice and Theory, 40(1), 29-50. https://doi.org/10.7459/ept/40.1.03

Edwards, S., Skouteris, H., Rutherford, L., \& Cutter-Mackenzie, A. (2012). 'It's all about Ben10 ${ }^{\text {TM': }}$ Children's play, health and sustainability decisions in the early years. Early Child Development and Care, 183(2), 280-293. https://doi.org/10.1080/03004430.2012.671816.

Elkind, D. (2007). The power of play: How spontaneous, imaginative activities lead to happier, healthier children. Cambridge: Da Capo Press.

Enrique Agudo, J., Rico, M., \& Sánchez, H. (2015). Multimedia games for fun and learning English in preschool. Digital Education Review, 27, 183-204.

Erdogan, N. I., Johnson, J. E., Dong, P. I., \& Qiu, Z. (2019). Do parents prefer digital play? Examination of parental preferences and beliefs in four nations. Early Childhood Education Journal, 47, 131-142. https://doi.org/10.1007/s10643-018-0901-2.

Faria, C., Guilherme, E., Pintassilgo, J., João Mogarro, M., Sofia Pinho, A., Baptista, M., Chagas, I., \& Galvão, C. (2019). The Portuguese Maritime Voyages of Discovery: the exploration of the history of a city with an App as an educational resource. Digital Education Review, 36, 85-99. https:// doi.org.skaitykla.mruni.eu/10.1344/der.2019.36.85-99

Fernández Batanero, J. M., Román Graván, P., \& Siles Rojas, C. (2020). Are primary education teachers from Catalonia (Spain) trained on ICT and disability? Digital Education Review, 37, 288-303.

Giovannella, C, Persico, D., \& Passarelli, M. (2020). Measuring the effect of the Covid-19 pandemic on the Italian Learning Ecosystems at the steady state: a school teachers' perspective. https:// www.researchgate.net/publication/343127257

González-Patiño, J. (2018). Learn, Teach and Share, Participation in Expanded Educational Communities: Madrid Pikler Seminar as a Practice of Continuing Education between Childhood Professionals. Digital Education Review, 33, 203-216.

Grané, M., \& Crescenzi, L. (2016). Modelo teórico para el diseño y evaluación de la calidad en las apps infantiles (0-8 años). (Spanish). Digital Education Review, 29, 227-245.

Hayashi, P., Abib, G., \& Hoppen, N. (2019). Validity in qualitative research: A processual approach. The Qualitative Report. doi:10.46743/2160-3715/2019.3443.

House, R. (2012). The inappropriateness of ICT in early childhood: Arguments from philosophy, pedagogy, and developmental research. In S. Suggate, \& E. Reese. Contemporary debates in childhood education and development, 105-120. New York: Routledge. https://doi-org.skaitykla.mruni.eu/10.1344/ der.2020.37.288-303

Yelland, N. (2006). New technologies and young children: Technology in early childhood education. Teacher Learning Network, 13(3), 10-13. Retrieved from http://search.informit.com.au/ fullText;res=AEIPT; $\mathrm{dn}=155999$

Imlawi, J., Gregg, D., \& Karimi, J. (2015). Student engagement in course-based social networks: The impact of instructor credibility and use of communication. Computers \& Education, 88, 84-96. https://doi.org/ 10.1016/j.compedu.2015.04.015

Youn, M. H., Leon, J., \& Lee, K. J. (2012). The influence of maternal employment on children's learning growth and the role of parental involvement. Early Childhood Development and Care, 182(9), 1227-1246. https://doi.org/10.1080/03004430.2011.604944

Yurt, Ö., \& Cevher-Kalburan, N. (2011). Early childhood teachers' thoughts and practices about the use of computers in early childhood education. Procedia Computer Science, 3, 1562-1570. https://doi.org/ 10.1016/j.procs.2011.01.050 
Jaisinghani, P. (2020). COVID-19 is widening the education gap. This is how we can stop it. https:// www.weforum.org/agenda/2020/08/we-must-resist-covid-19-widening-us-education-gap

Kim, J.(2020). Learning and Teaching Online During Covid-19: Experiences of Student Teachers in an Early Childhood Education Practicum. International Journal of Early Childhood, 52, 145-158. https:// doi.org/10.1007/s13158-020-00272-6

King, N., \& Brooks, J. (2018). Thematic Analysis in Organisational Research. C. Cassell, A. Cunliffe, \& G. Grandy, The SAGE Handbook of Qualitative Business and Management Research Methods: Methods and Challenges, 219-236. London: SAGE Publications Ltd.

Kjærgaard, E., ir Martinènienè, R. (1998). Penki sveikinimai demokratijai. Vilnius: Garnelis.

Konca, A. S., Ozel, E., \& Zelyurt, H. (2016). Attitudes of preschool teachers towards using information and communication technologies (ICT). International Journal of Research in Education and Science (IJRES), 2(1), 10-15. https://doi.org/10.21890/ijres.21816

König, J., Jäger-Biela, D.J., \& Glutsch, N. (2020). Adapting to online teaching during COVID19 school closure: teacher education and teacher competence effects among early career teachers in Germany. European Journal of Teacher Education, 43(4), 608-622. https://doi.org/10.1080/02619768.2020.1809650

Kvale, S. (1994). Validation as Communication and Action: On the Social Construction of Validity. New Orleans, LA: ERIC.

Levin, S., Whitsett, D., \& Wood, G. (2013). Teaching MSW social work practice in a blended online learning environment. Journal of Teaching in Social Work, 33(4-5), 408-420. https://doi.org/ $10.1080 / 08841233.2013 .829168$

Li, Ch \& Lalani, F. (2020). The COVID-19 pandemic has changed education forever. This is how. World Economic Forum. https://www.weforum.org/agenda/2020/04/coronavirus-education-global-covid19online-digital-learning/

Liamputtong, P. (2011). Focus Group Methodology: Principles and Practice. London: SAGE Publications Ltd.

Lindahl, M. G., \& Folkesson, A. M. (2012). ICT in preschool: Friend or foe? The significance of norms in a changing practice. International Journal of Early Years Education, 20(4), 422-436. https://doi.org/ $10.1080 / 09669760.2012 .743876$

Liu, F., Black, E., Algina, J., Cavanaugh, C., \& Dawson, K. (2010). The validation of one parental involvement measurement in virtual schooling. Journal of Interactive Online Learning, 9(2), 105-132.

Machynska, N., \& Dzikovska, M. (2020). Challenges to Manage the Educational Process in the HEI during the Pandemic. Romanian Journal for Multidimensional Education, 12, 92-99.

Makrooni, G. (2019). Being a First-Generation Migrant Family Student in Finland: Perceptions and experiences of the Educational Journey to Higher Education. Journal of Ethnic and Cultural Studies, 6(3), 157-170. http://dx.doi.org/10.29333/ejecs/293

Manches, A., \& Plowman, L. (2017). Computing education in children's early years: A call for debate. British Journal of Educational Technology, 48(1), 191-201. https://doi.org/10.1111/bjet.12355

McPake, J., Plowman, L., \& Stephen, C. (2013). Preschool children creating and communicating with digital technologies in the home. British Journal of Educational Technology, 44(3), 421-431. https://doi.org/ 10.1111/j.1467-8535.2012.01323.x

Miller, T., Birch, M., Mauthner, M., \& Jessop, J. (2012). Ethics in Qualitative Research. London: SAGE Publications Ltd.

Miño Puigcercós, R. (2018). Young people's learning trajectories in the digital age. Digital Education Review, 33, 39-54.

National Education Responses to COVID-19: Summary report of UNESCO's online survey (2020). UNESCO's Section of Education Policy in the Division of Policies and Lifelong Learning Systems. https:// unesdoc.unesco.org/ark:/48223/pf0000373322 
Onwuegbuzie, A. J., W. B. Dickinson, N. L. Leech, and A. G. Zoran. 2009. "A Qualitative Framework for Collecting and Analysing Data in Focus Group Research." International Journal of Qualitative Methods 8 (3): 1-21. doi:10.1177/160940690900800301.

Orr, D., Weller, M., \& Farrow, R. (2019). How is digitalization affecting the flexibility and openness of higher education provision? Results of a global survey using a new conceptual model. Journal of Interactive Media in Education, 2019 (1). https://doi.org/10.5334/jime. 523

Patton, M. Q. (2014). Qualitative research \& evaluation methods: Integrating theory and practice. Sage publications.

Plowman, L., Stevenson, O., McPake, J., Stephen, C., \& Adey, C. (2011). Parents, preschoolers and learning with technology at home: some implications for policy. Journal of Computer Assisted learning, 27, 361-371. https://doi.org/10.1111/j.1365-2729.2011.00432.x

Preradovic, N. M., Lesin, G., \& Boras, D. (2016). Introduction of Digital Storytelling in Preschool Education: A Case Study from Croatia. Digital Education Review, 30, 94-105.

Reynolds, A. J., Ou, S., \& Temple, J. (2018). A multicomponent, preschool to third grade preventive intervention and educational attainment at 35 years of age. Journal of the American Medical Association Pediatrics, 172, 247-256. https://doi.org//10.1001/jamapediatrics.2017.4673

Renner, D., Laumer, S., \& Weitzel, T. (2014). Effectiveness and efficiency of blended learning: A literature review. 20th Americas conference on information systems proceedings 7-9 August 2014. https:// pdfs.semanticscholar.org/7362/4516b3ea78b0477f0639a87e3429cc8f3255.pdf? _ga $=2.164162875 .50848195 .1588235235-1386605532$. 1551621031

Roache, D., Rowe-Holder, \& Richard Muschette, D. (2020). Transitioning to Online Distance Learning in the COVID-19 Era: A Call for Skilled Leadership in Higher Education Institutions. International Studies in Educational Administration, 48 (1), 103-110.

Schroeder, V. M., \& Kelley, M. L. (2010). Family environment and parent-child relationships as related to executive functioning in children. Early Child Development and Care, 180(1), 1285-1298. https:// doi.org/ $\underline{10.1080 / 03004430902981512}$

Stone, C., Freeman, E., Dyment, J. E., Muir, T., \& Milthorpe, N. (2019). Equal or equitable? The role of flexibility within online education. Australian \& International Journal of Rural Education, 29(2). https:// journal.spera.asn.au/index.php/AIJRE/article/ view/221

Tam, G \& El-Azar, D. (2020). 3 ways the coronavirus pandemic could reshape education. World Economic Forum. https://www.weforum.org/agenda/2020/03/3-ways-coronavirus-is-reshaping-education-andwhat-changes-might-be-here-to-stay

Terenko, O., \& Ogienko, O. (2020). How to Teach Pedagogy Courses Online at University in COVID-19 Pandemic: Search for Answers. Romanian Journal for Multidimensional Education, 12, 173-179. https://doi.org/10.10.18662/rrem/12.1sup2/261

Willis, L.-D., \& Exley, B. (2018). Using an Online Social Media Space to Engage Parents in Student Learning in the Early-Years: Enablers and Impediments. Digital Education Review, 33, 87-104.

Woofter, S. (2019). Book Review: Building Equity: Policies and Practices to Empower All Learners. American Journal of Qualitative Research, 3(1), 136-139. https://doi.org/10.29333/ajar/5815 